\title{
Effects of soil mechanical treatments combined with bramble and bracken control on the restoration of degraded understory in an ancient beech forest
}

\author{
Sandrine Godefroid ${ }^{a *}$, Dennis Monbaliu ${ }^{\mathrm{a}}$, Wim MASSANT ${ }^{\mathrm{a}}$, Beatrijs VAN DER AA ${ }^{\mathrm{b}}$, Bruno De Vos ${ }^{\mathrm{b}}$, \\ Vincent QUIVY ${ }^{\mathrm{c}}$, Nico KOEDAM ${ }^{\mathrm{a}}$ \\ ${ }^{a}$ Laboratory of Plant Biology and Nature Management (APNA), Vrije Universiteit Brussel, Pleinlaan 2, 1050 Brussels, Belgium \\ ${ }^{\mathrm{b}}$ Institute for Forestry and Game Management (IBW), Gaverstraat 4, 9500 Geraardsbergen, Belgium \\ c Département Génie Rural, Centre de Recherches Agronomiques de Gembloux (CRAGx), Chaussée de Namur 146, 5030 Gembloux, Belgium
}

(Received 28 June 2006; accepted 27 September 2006)

\begin{abstract}
This paper describes the ground floor vegetation that developed four years after tillage implements in an ancient beech forest in central Belgium. The purpose of this study was twofold: (1) to explore whether tillage has a lasting effect on soil compaction and soil moisture as well as on vegetation characteristics; and (2) to analyse whether two distinct tillage treatments (rotary plough vs. disc plough), combined with vegetation control when necessary, have the same effect on soil compaction, soil moisture and plant establishment. Of the 29 species recorded, 15 showed a significant recovery after soil loosening in the studied forest area. Interestingly, different tillage treatments did not have the same influence on plant establishment. Treatment effects on soil structure and/or moisture status can be considered as causing the observed growth response.
\end{abstract}

ancient forest species / forest understory / soil compaction / soil tillage / soil loosening technique

Résumé - Effets de traitements mécaniques du sol combinés à un contrôle de la ronce et de la fougère aigle sur la restauration d'un sous-bois dégradé dans une ancienne hêtraie. Cette étude décrit la flore herbacée qui s'est développée quatre années après la mise en place d'expériences de traitement mécanique du sol dans une ancienne hêtraie dans le centre de la Belgique. Les objectifs furent : (1) explorer si le traitement mécanique du sol a un effet durable sur la compaction et l'humidité du sol et sur les caractéristiques de la végétation; et (2) analyser si deux traitements effectués avec des machines différentes (crabe et fraise rotative), combinés à un contrôle de la végétation si nécessaire, ont le même effet sur la compaction et l'humidité du sol et sur l'établissement des plantes. Parmi les 29 espèces inventoriées, 15 ont montré un développement significatif suite au labour du sol dans les zones expérimentales étudiées. Il est intéressant de constater que les différents traitements n'ont pas eu la même influence sur l'établissement des espèces végétales. L'effet des traitements sur la structure et/ou l'humidité du sol peut être considéré comme étant la cause de la réponse végétale observée.

espèces des forêts anciennes / sous-bois / compaction du sol / labour du sol / technique d'ameublissement du sol

\section{INTRODUCTION}

Soil degradation, especially compaction, due to traffic with heavy machinery is a problem which may rise in the future due to increasing machinery weight [43]. It has been considered a principal form of damage due to logging [65]. Soil compaction during timber harvesting typically alters soil structure and hydrology by increasing bulk density, breaking down aggregates, decreasing porosity, aeration and infiltration capacity; and by increasing soil strength, water runoff, erosion and waterlogging $[25,41,57]$. Practical experience shows that deformation symptoms (skid trails) on loess loam sites remain visible for years or even decades [18] due to the fact that interruption of biotic energy transfer in the mineral soil is a long-term consequence [32]. Persistence of soil compaction is also likely to

*Corresponding author: sagodefr@vub.ac.be vary with abiotic factors such as degree of compaction, depth of compacting soil layer, soil type and climate [52].

Soil compaction can severely reduce plant development by restricting root growth and lowering the percentage of water and air space in the soil [36]. The influence of soil compaction on plant species has been studied mainly on crop plants (e.g. $[7,28,53])$ or trees (e.g. $[5,24,41])$, but rarely on forest herbs (but see $[9,21,55]$ ).

How to solve the problem of soil compaction is a very controversal topic. If the forest floor cannot be restored in a natural way after compaction due to the lack of active soil fauna, the mechanical loosening of the upper soil will be a necessary measure [13]. This ploughing or harrowing of soil is usually called tillage in the literature. Tillage breaks up plants, mixes biomass-rich top layers with deeper layers, aerates the soil, affects the soil's temperature regime and hastens soil drying $[40,44]$. The tillage of damaged soils shows promise in 
reducing the risk associated with mechanized forestry operations [17]. It has been frequently carried out as a way to loosen compact soil (e.g. [3, 20,38]), although some authors have highlighted the fact that compaction may also be induced by tillage tools $[8,41,60]$. Loosening the soil tends to hasten the drying of the tilled layer, but may subsequently reduce the upward movement of moisture from the layers below [35]. Tillage might thus produce either a larger or smaller evaporative loss than would have occurred from the undisturbed soil, the net effect depending on duration of the process, as well as on the depth, degree, and frequency of tillage [35]. The effect of tillage on soil status has frequently been investigated in agricultural environments (e.g. [11, 19, 45]), whereas very few studies have been carried out in forest conditions (but see $[10,20,38])$. Moreover, studies investigating the effect of tillage on bulk density and water infiltration have led to contradictory and inconclusive results due to variability of soils different researchers worked on [29].

Soil moisture and soil temperature conditions in the seedbed zone (top $5 \mathrm{~cm}$ ) can promote or delay seed germination and plant emergence [39]. According to Azooz et al. [4], no-tillage results in cold soil temperature and reduced germination. As it has been shown that even a difference of $1{ }^{\circ} \mathrm{C}$ in soil temperature can affect forest herb development [23], growth and development of early forest herb could therefore significantly be reduced under no-tillage conditions. Mechanical tillage can alter the balance of air and water in soil necessary for optimum plant growth [1]. Effective tillage systems can create an ideal seedbed condition (i.e. soil moisture, temperature, and penetration resistance) for plant emergence, plant development, and unimpeded root growth. Therefore, quantifying the effects of tillage systems on soil moisture, temperature, and compaction can help explain some of the differences in plant growth and development in different tillage systems [45]. The influence of soil loosening on plant development has been widely studied on crop plants (e.g. $[2,56])$, but no attempt has been made so far to relate forest herb response to tillage.

Tillage-induced soil conditions have been found to decline as time progresses $[5,20,66]$. Treatment effects are expected to become more pronounced in subsequent years as seedling establishment effects diminish further [10]. According to Birkas et al. [8], this effect is only felt for a single season or less. The major cause of the decline is normally cumulative rainfall: a rough cloddy surface will gradually be smoothed by raindrop energy [29]. Most of the studies dealing with the influence of tillage on the physical state of the soil have been carried out immediately after soil loosening. To our knowledge, no study has investigated the persistence of this effect a few years after the implementation of the experiments.

This paper described the ground floor vegetation that developed four years after tillage implements in an ancient beech forest in central Belgium. The purpose of these investigations was twofold: (1) to explore whether tillage has a long-lasting effect on soil compaction and soil moisture, as well as on vegetation characteristics; and (2) to analyse whether two distinct tillage treatments (rotary plough vs. disc plough), combined with vegetation control when necessary, have the same effect on soil compaction, soil moisture and on plant establishment.

\section{STUDY AREA}

The research was conducted in the Sonian Forest, south of Brussels $\left(50^{\circ} 47^{\prime} \mathrm{N} ; 4^{\circ} 26^{\prime} \mathrm{E}\right)$. Almost the whole surface (4383 ha) of the forest (95\%) is composed of a 3-4 m thick silt loam layer $\left(\mathrm{pH}_{\mathrm{H} 2 \mathrm{O}}\right.$ between 4.0 and 4.5 in the upper $\left.10 \mathrm{~cm}\right)$, which corresponds to the loess deposition after decalcification. The forest ranges in altitude from 65 to $130 \mathrm{~m}$ a.s.l. The climate of the area is temperate and humid, with a growing season of 7 months (April-October). Mean annual temperature is $9.9{ }^{\circ} \mathrm{C}$, annual precipitation is $798 \mathrm{~mm}$ [46]. The natural vegetation is a deciduous forest in which oaks (Quercus robur and Quercus petraea) and beech (Fagus sylvatica) are the main species [30]. Since the plantation work of the Austrian administration at the end of the 18th century, it is now composed of $74 \%$ beech (Fagus sylvatica) with only a few other woody species [63]. Soil compaction occurs naturally between 40 and $120 \mathrm{~cm}$ of depth (fragipan) as a result of an intense postglacial drying, but is also anthropogenically induced in the topsoil by heavy machinery, horse trails, pedestrian traffic, scouting and mountain biking. Results of Herbauts et al. [30,31] already provide evidence that on these loess materials soil compaction due to logging operations leads to rapid soil degradation through active hydromorphic processes.

\section{METHODS}

\subsection{Soil and vegetation treatments}

Four beech stands sharing comparable silvicultural characteristics were selected (Tab. I). Each stand had a different type of understory vegetation, i.e. dominated by Holcus mollis, Pteridium aquilinum, Rubus fruticosus, or without any herbaceous vegetation. These differences in understory are due to a combination of factors related to silviculture (some trees were cut) and natural events (windthrow). Soil conditions were homogeneous in each of the four stands, showing an "Abc" profile, i.e. silt loam soil with textural B horizon according to the Belgian Soil Map [47] (USDA: Hapludalf; FAO: Luvisol; French classification: Sol lessivé acide). In each stand, one experimental area was delimited, ranging from 5787 to $10735 \mathrm{~m}^{2}$. Our experiment was carried out in a strip design, each of the four areas being divided in 10 to 13 strips of $3 \mathrm{~m}$ width. There were no buffer areas between the strips. Each strip was submitted to one soil treatment combined or not with vegetation treatments. Vegetation treatments were only meant to reduce the huge development of the understory (only in the case of stands dominated by Pteridium aquilinum or Rubus fruticosus) in order to make tillage possible. Two strips in each stand were left without treatment as control. An overview of the experimental design is given in Table II.

For the tillage experiments, two types of tractor-towed machines suited to the work of not-cleared forest grounds were used: a rotary plough (= rototiller or blade cultivator), which is the machine used for the majority of soil tillage operations carried out in the past in the Sonian Forest, and a disc plough, a machine of which the use is 
Table I. Silvicultural characteristics of the four studied beech stands. $H$ dom: dominant height, defined as the average height of the 5 highest trees. $V$ : wood volume, calculated according to the volume equation in function of the individual circumference and the dominant height [12]. $G$ : basal stand area, based on the inventory of individual circumferences.

\begin{tabular}{lcccccc}
\hline Understory & Stand age $(\mathrm{y})$ & H dom $(\mathrm{m})$ & No. stems/ha & C150 $(\mathrm{cm})$ & $V\left(\mathrm{~m}^{3} / \mathrm{ha}\right)$ & $G\left(\mathrm{~m}^{2} / \mathrm{ha}\right)$ \\
\hline No vegetation & $120-125$ & 40 & 98 & 177 & 414 & 26 \\
Holcus mollis & $140-146$ & 43 & 98 & 77 & 211 & 599 \\
Pteridium aquilinum & $132-140$ & 42 & 94 & 183 & 459 & 444 \\
Rubus fruticosus & $135-157$ & 41 & 27 & 27 \\
\hline
\end{tabular}

Table II. Experimental design of soil and vegetation treatments in the four studied stands. Empty columns are control strips. Shaded areas show strips that are absent in some stands.

\begin{tabular}{|c|c|c|c|c|c|c|c|c|c|c|c|c|c|c|}
\hline \multirow[b]{2}{*}{ Understory } & \multirow[b]{2}{*}{ Treatment } & \multicolumn{13}{|c|}{ Experimental strips and date of treatment } \\
\hline & & A & B & C & D & E & $\mathbf{F}$ & G & H & $\mathrm{I}$ & $\mathbf{J}$ & K & $\mathbf{L}$ & M \\
\hline \multirow[t]{10}{*}{ Pteridium aquilinum } & Brush cutter & $25 / 09 / 00$ & & & $25 / 09 / 00$ & & & & $25 / 09 / 00$ & & & & & \\
\hline & Disc plough & $25 / 09 / 00$ & $25 / 09 / 00$ & & $25 / 09 / 00$ & $25 / 09 / 00$ & & & $25 / 09 / 00$ & & & & & \\
\hline & Rotary plough & & & & & & $26 / 09 / 00$ & $26 / 09 / 00$ & & $26 / 09 / 00$ & & & & \\
\hline & Land roller & & & & & & & & & & & & & \\
\hline & Clearing saw & $31 / 05 / 01$ & $31 / 05 / 01$ & & & & & $31 / 05 / 01$ & $31 / 05 / 01$ & $31 / 05 / 01$ & & & & \\
\hline & & $31 / 05 / 02$ & $31 / 05 / 02$ & & & & & $31 / 05 / 02$ & $31 / 05 / 02$ & $31 / 05 / 02$ & & & & \\
\hline & & $28 / 05 / 03$ & $28 / 05 / 03$ & & & & & $28 / 05 / 03$ & $28 / 05 / 03$ & $28 / 05 / 03$ & & & & \\
\hline & Tooth harrow & & & & & & & & & & & & & \\
\hline & Asulam & & & & & $25 / 07 / 01$ & $25 / 07 / 01$ & & & & & & & \\
\hline & Glyphosate & & & & & & & & & & & & & \\
\hline \multirow[t]{8}{*}{ No vegetation } & Brush cutter & & & & & & & & & & & & & \\
\hline & Disc plough & $25 / 09 / 00$ & $25 / 09 / 00$ & $25 / 09 / 00$ & & & & & $10 / 01 / 01$ & & & $25 / 09 / 00$ & & \\
\hline & Rotary plough & & & & & $26 / 09 / 00$ & $26 / 09 / 00$ & $26 / 09 / 00$ & & $10 / 01 / 01$ & $10 / 01 / 01$ & & $26 / 09 / 00$ & \\
\hline & Land roller & & & $10 / 01 / 01$ & & & & $10 / 01 / 01$ & & & $10 / 01 / 01$ & & & \\
\hline & Clearing saw & & & & & & & & & & & & & \\
\hline & Tooth harrow & & & & & & & & & & & & & \\
\hline & Asulam & & & & & & & & & & & & & \\
\hline & Glyphosate & & & & & & & & & & & & & \\
\hline \multirow[t]{8}{*}{ Holcus mollis } & Brush cutter & & & & & & & & & & & & & \\
\hline & Disc plough & $25 / 09 / 00$ & $25 / 09 / 00$ & $25 / 09 / 00$ & & & & & $10 / 01 / 01$ & & & $25 / 09 / 00$ & & \\
\hline & Rotary plough & & & & & $26 / 09 / 00$ & $26 / 09 / 00$ & $26 / 09 / 00$ & & $10 / 01 / 01$ & $10 / 01 / 01$ & & $26 / 09 / 00$ & \\
\hline & Land roller & & & $10 / 01 / 01$ & & & & $10 / 01 / 01$ & & & $10 / 01 / 01$ & & & \\
\hline & Clearing saw & & & & & & & & & & & & & \\
\hline & Tooth harrow & & & & & & & & & & & & & \\
\hline & Asulam & & & & & & & & & & & & & \\
\hline & Glyphosate & & & & & & & & & & & & & \\
\hline \multirow[t]{10}{*}{ Rubus fruticosus } & Brush cutter & $28 / 09 / 00$ & $28 / 09 / 00$ & $25 / 09 / 00$ & $25 / 09 / 00$ & $25 / 09 / 00$ & & $25 / 09 / 00$ & $25 / 09 / 00$ & $25 / 09 / 00$ & $28 / 09 / 00$ & & & \\
\hline & Disc plough & & $28 / 09 / 00$ & $28 / 09 / 00$ & $28 / 09 / 00$ & $28 / 09 / 00$ & & & & & $28 / 09 / 00$ & & & \\
\hline & Rotary plough & $28 / 09 / 00$ & & & & & & $28 / 09 / 00$ & $28 / 09 / 00$ & $28 / 09 / 00$ & & & & \\
\hline & Land roller & & & & & & & & & & & & & \\
\hline & Clearing saw & & & & $11 / 07 / 01$ & & & & $11 / 07 / 01$ & & & & & \\
\hline & & & & & $1 / 07 / 02$ & & & & $1 / 07 / 02$ & & & & & \\
\hline & & & & & $27 / 06 / 03$ & & & & $27 / 06 / 03$ & & & & & \\
\hline & Tooth harrow & & & & & $29 / 08 / 02$ & & $29 / 08 / 02$ & & & & & & \\
\hline & Asulam & & & & & & & & & & & & & \\
\hline & Glyphosate & $20 / 09 / 00$ & $20 / 09 / 00$ & $29 / 01 / 02$ & & & & & & $29 / 01 / 02$ & $20 / 09 / 00$ & & & \\
\hline
\end{tabular}

very common in beechwoods managed by the French Forest Office (ONF). The rotary plough finely fragments and mixes the vegetation together with subjacent humus and mineral horizons down to a depth of $30 \mathrm{~cm}$. It consists of a series of blades mounted on a revolving power-driven shaft. The diameter of the rotor reaches $60 \mathrm{~cm}$. A total of 19 strips within the four experimental areas were treated with the rotary plough when the soil was relatively dry (avoiding therefore the loss of soil structure). The disc plough is made up of two rows of four crenellated discs from 60 to $70 \mathrm{~cm}$ in diameter whose concavity is turned forwards. Each disc is connected to the chassis by the intermediary of an arm allowing its individual raising, as well as a lateral displacement in case of encountering an obstacle. The disc plough turns the soil down to a maximum depth of $30 \mathrm{~cm}$. A total of 20 strips within the four experimental areas were treated with the disc plough when the soil was relatively dry (avoiding therefore the loss of soil structure). 
Cutting experiments were also carried out before tillage in case of bramble (Rubus fruticosus) or bracken (Pteridium aquilinum) undergrowth. This aimed at improving the quality of tillage experiments, and was implemented by means of a brush cutter, i.e. a tool with a horizontal blade with a cutting capacity of $1 \mathrm{~m}$ in diameter that cuts undergrowth and brush while mulching. A total of 12 strips within these experimental areas were treated with the brush cutter.

In the two sites dominated by bramble or bracken, herbicides were applied on seven strips, in order to facilitate the reduction of their development. Glyphosate was used on bramble (Rubus fruticosus) 8 days before brush cutting and tillage (2 $160 \mathrm{~g}$ of active matter/ha with addition of a surfactant, sprayed with a back spray), and 16 months after tillage on the resprout ( $720 \mathrm{~g}$ of active matter/ha without addition of a surfactant, sprayed with a back spray). Asulam was used on bracken (Pteridium aquilinum) ten months after tillage on the resprout (4 $000 \mathrm{~g}$ of active matter/ha without addition of a surfactant). Between May and July of each year after tillage implementation, the development of bramble and bracken was then further reduced by the use of a clearing saw. A total of seven strips within these two experimental areas were treated with the clearing saw.

During the second vegetation season after tillage experiments, bramble resprouts were uprooted with a tooth harrow in two experimental strips. This machine has eight peg-shaped teeth attached to a rectangular frame. It was applied above ground and acted as a comb against bramble. It was designed and manufactured by the Department of Agricultural engineering of the Agronomical Research Centre of Gembloux (Belgium) on the basis of models developed by the National Forest Office (ONF) in France.

Finally, the benefit of using the land roller was also investigated in two sites, as this technique is sometimes used for optimising seed bed conditions [49]. The land roller we used was a steel cylinder roller attached to a rectangular frame and towed by a tractor. Its use provided a smooth and level surface (push down soil ridges) for better seed-tosoil contact. A total of six strips within two of the four experimental areas were treated with the land roller.

\subsection{Vegetation sampling}

Within each strip, the vegetation was sampled during May and June 2004 in eight $1 \mathrm{~m} \times 1 \mathrm{~m}$-plots at $2 \mathrm{~m}$ intervals, which makes a total of 376 plots $(10+13+13+11$ strips in the 4 stands $\times 8$ plots per strip). The $1 \mathrm{~m}^{2}$-plots were placed in the middle of each strip and thus at a distance of $1 \mathrm{~m}$ from the limit between two treatments. The species composition was characterized by the classical phytosociological method (e.g. [64]), which means that total coverage for each species (vertical projection onto the ground) was estimated visually, and recorded within seven cover classes: $\mathbf{r}$ : 1 or 2 individuals; +: few individuals $(<20)$ with cover $<5 \%$; 1 : many individuals $(20-100)$ with cover $<5 \% ; 2$ : 5-25\% cover; 3: $25-50 \%$ cover; $4: 50-75 \%$ cover; 5: $75-100 \%$ cover.

\subsection{Recording of soil compaction and moisture}

In each of the 376 sample plots, four measurements of soil compaction were recorded using a cone-penetrometer (Eijkelkamp Agrisearch Equipment, The Netherlands), a device forced into the soil to measure its resistance to vertical penetration as frequently used to measure soil resistance (e.g. [37,54]). The four measurements were taken each time according to the same design, i.e. at $30 \mathrm{~cm}$ from the plot corners along the plot diagonals. The average value was taken for statistical analyses. Measurements were performed down to $20 \mathrm{~cm}$ depth, as the $0-20 \mathrm{~cm}$ depth range is the most relevant for the root development of herbaceous species, and because it is situated within the working depth of our ploughing machines.

Soil moisture content was measured next to the compaction measurements, using a Theta Probe (Delta-T Devices Ltd., UK). The Theta Probe measures volumetric soil moisture content (the ratio between the volume of water present and the total volume of the sample) by applying power to the sensor and measuring the output signal voltage returned. The device converts the $\mathrm{mV}$ reading into soil moisture units using conversion tables and soil-specific parameters. In each of the 376 sample plots, four measurements of soil moisture were recorded at a specific date. The average value was taken for statistical analyses. In order to get comparable compaction and moisture data, field samplings were carried out during a short time span (May and June 2004).

\subsection{Data analyses}

Since Braun-Blanquet cover-abundance values are not suitable for mathematical treatment, raw data were transformed by the correspondent cover percentage value (median of each scale interval): 87.5 ; $62.5 ; 37.5 ; 15 ; 2.5 ; 0.5 ; 0.2$ accounting respectively for $5 ; 4 ; 3 ; 2 ; 1$; $+; \mathrm{r}$ (arbitrary values where taken for + and $\mathrm{r}$ ).

Site conditions other than those which were measured were estimated using Ellenberg's indicator values (soil nutrients, acidity, moisture, and light intensity). The indicator value approach is interesting because plants integrate seasonally environmental variations and extremes, while unique measurements reflect environmental conditions at a single moment in time, which may sometimes be misleading. Because species are not always constant in their ecological requirements and ought in principle to have different indicator values in different parts of their range, we used the re-calibrated Ellenberg's indicator values for the British Isles [33], which are phytogeographically closer to our study area, instead of the original ones which were defined for Central Europe [15]. Weighted averages of Ellenberg's indicator values $\left(\mathrm{WA}_{\mathrm{E}}\right)$ were calculated for each sample plot using the following equation:

$$
\mathrm{WA}_{\mathrm{E}}=\frac{\left(x_{1} y_{1}+x_{2} y_{2}+\ldots+x_{\mathrm{n}} y_{\mathrm{n}}\right)}{\left(x_{1}+x_{2}+\ldots+x_{\mathrm{n}}\right)}
$$

Where $x_{1}, x_{2}, \ldots, x_{\mathrm{n}}$ are the cover-abundance values of those species present in the relevé, and $y_{1}, y_{2}, \ldots, y_{n}$ represent Ellenberg's indicator values, either for soil nutrients, acidity, moisture or light intensity.

Species richness refers to the total number of plant species present in a plot $\left(1 \mathrm{~m}^{2}\right)$. Species diversity of each plot was calculated using the Shannon index $H$ :

$$
H=-\Sigma p_{i} \ln p_{i}
$$

Where $p_{i}$ is the proportion of species $i$ relative to the total number of species present in the relevé.

Forest species are determined according to Stieperaere and Fransen [59]. The composition of plant communities was also examined with special reference to species' ecological strategies (C-S-R model), according to Grime et al. [26]. To convert these strategies to numerical values, we used the three-dimension linear interpolation of [34]: $C$ (competitor) $=(10,0,0) ; S$ (stress tolerator) $=(0,10,0) ; \mathrm{R}$ (ruderal) $=(0,0,10) ; \mathrm{SR}$ (stress-tolerant 


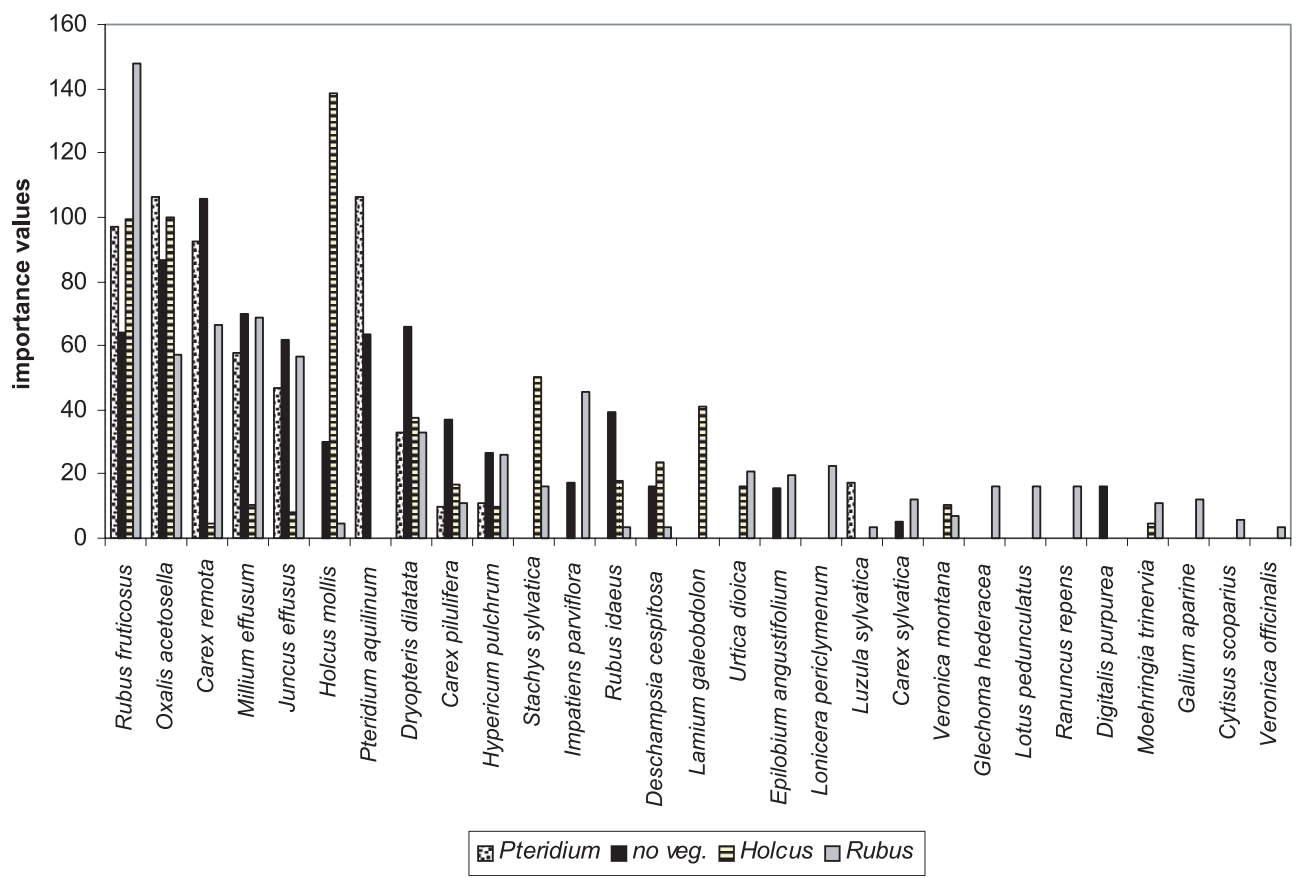

Figure 1. Herbaceous species which developed four years after treatments in the experimental areas (main feature of understory before treatment is given in the graph legend). Data are importance values based on sum of relative cover and relative frequency. Species are ranked according to their decreasing mean importance value.

ruderal $)=(\mathrm{S}+\mathrm{R}) / 2=(0,5,5) ; \mathrm{CSR}$ (completely intermediate $)=(\mathrm{C}+\mathrm{S}+\mathrm{R}) / 3=(3.3,3.3,3.3) ; \mathrm{C} / \mathrm{CSR}=(\mathrm{C}+\mathrm{CSR}) / 2=(6.7$, $1.7,1.7)$ etc. By definition the $\mathrm{C}+\mathrm{S}+\mathrm{R}$-values sum to 10 . With these values a weighted average $\left(\mathrm{WA}_{\mathrm{G}}\right)$ was calculated resulting in a $\mathrm{C}, \mathrm{S}$ and $\mathrm{R}$-value for each relevé.

$$
\mathrm{WA}_{\mathrm{G}}=\frac{\left(x_{1} y_{1}+x_{2} y_{2}+\ldots+x_{\mathrm{n}} y_{\mathrm{n}}\right)}{\left(x_{1}+x_{2}+\ldots+x_{\mathrm{n}}\right)}
$$

Where $x_{1}, x_{2}, \ldots, x_{\mathrm{n}}$ are the cover-abundance values of those species present in the relevé, and $y_{1}, y_{2}, \ldots, y_{\mathrm{n}}$ represent Grime's strategies, either for competitors, stress-tolerators or ruderals.

In order to detect the patterns of variation in species data that can be explained by management and soil variables, we calculated a Canonical Correspondence Analysis (CCA) [61] using Canoco 4.5 for Windows [62]. Eight explanatory variables were categorical variables (asulam, glyphosate, brush cutter, clearing saw, harrow, land roller, disc plough, rotary plough). The two remaining variables were quantitative (soil compaction and moisture). The site effect was removed (partialled out) by using the four stands as covariables.

In order to check the effect of management and soil variables at the species level, we used the Indicator Species Analysis according to Dufrêne and Legendre [14], as available in the PC-ORD package [48]. This analysis was performed to determine indicator species for the categorical variables studied with the CCA. The method combines information on the concentration of species abundance in a particular group of samples (represented here by one treatment) and the faithfulness of occurrence of a species in that group. It produces indicator values for each species in each group, which are tested for statistical differences using a Monte Carlo technique with 1000 permutations [14]. This method allowed us to identify species that have a significant response to the treatments.
Using the package Statistica Version 6.0 [58], we performed Mann-Whitney U-tests to explore the relationships between each treatment and soil characteristics, Grime's strategies, mean Ellenberg's indices, species richness or diversity and number of forest herbs. The 0.05 level of probability was accepted as significance limit throughout the work. Nomenclature follows Lambinon et al. [42]. The highly variable and taxonomically disputed Rubus fruticosus agg. was considered a single species.

\section{RESULTS}

A total of 29 taxa were found (Fig. 1). The most important species being found in all tilled areas were Rubus fruticosus, Oxalis acetosella, Carex remota and Millium effusum.

The ordination of species and environmental parameters along the first two axes of the CCA is shown in Figure 2. Table III shows the variance explained by each of the variables tested. Glyphosate was the most powerful predictor, explaining $21 \%$ of the total variance in the dataset. Soil compaction also explained a significant amount of variation (14\%) in the species composition. Rotary plough and roller explained each $11 \%$ of the floristic variation. Clearing saw and disc plough explained each $7 \%$ of the variation, soil moisture and asulam $4 \%$. Harrow and brush cutter did not significantly contribute to the variation in the dataset.

At the species level (Tab. IV), brush cutting had a positive effect mainly on Carex remota and Juncus effusus, while clearing saw also favoured Dryopteris dilatata and Veronica montana. Harrowing only had a positive influence on Rubus fruticosus. Disc ploughing promoted the development of among 


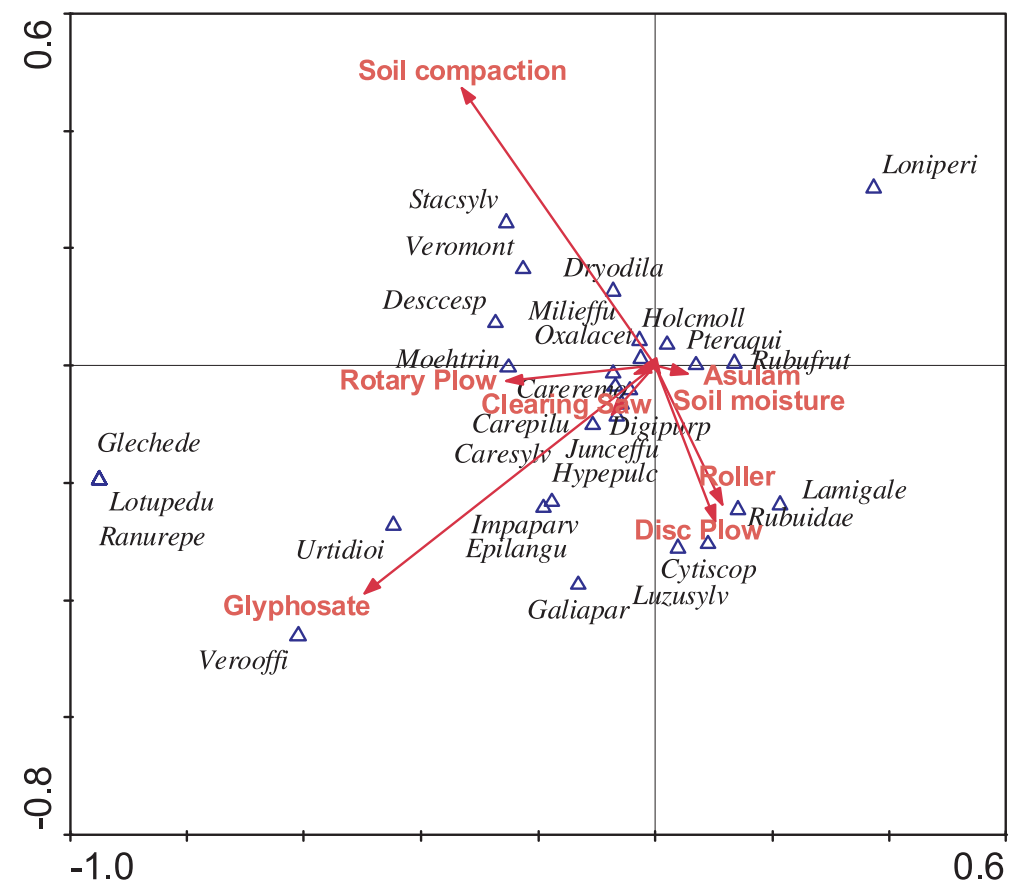

Figure 2. Species ordination diagram based on Canonical Correspondence Analysis, with respect to two quantitative variables (soil compaction and moisture) and eight nominal variables (asulam, glyphosate, brush cutter, clearing saw, disc plow, roller, rotary plow, harrow). For legibility reasons, only the species having the best fit are represented. The axes (1: horizontal; 2: vertical) are scaled in standard deviation units. Eigenvalues of first and second axis were: site 0.087 and 0.052 , respectively. Species abbreviations are based on the first four letters of genus and species names (for full names, see Fig. 1).

others Holcus mollis, Impatiens parviflora, Lamium galeobdolon, Stachys sylvatica, while rotary ploughing favoured other species such as Epilobium angustifolium, Oxalis acetosella, Pteridium aquilinum, Rubus idaeus and Urtica dioica. The use of the land roller after tillage affected few species, a.o. Dryopteris dilatata and Hypericum pulchrum. Asulam had a negative effect on Juncus effusus and Pteridium aquilinum. Glyphosate strongly limited the cover of Rubus fruticosus (as desired), but consequently promoted the development of Carex remota, Impatiens parvifora, Juncus effusus, Oxalis acetosella and Urtica dioica.

When comparing the influence of different vegetation and soil treatments on soil parameters (Tab. V), we found that brush cutter and clearing saw had not the same effects. The former had a negative influence on soil moisture, $\mathrm{pH}$ and nutrients in the Rubus stand, while the latter showed a positive influence on these soil variables in the Pteridium stand. Harrow did not have any effect on the considered soil parameters. Both disc and rotary ploughing induced an overall lowering of soil nutrient index and soil compaction, but different or mitigated influences on soil moisture and $\mathrm{pH}$ were observed.

Vegetation and soil treatments also had significant effects on plant functional groups and on the number of species (Tab. V). Brush cutter and clearing saw induced a reduction of competitive species, while improving the species richness. However, brush cutting also promoted the development of ruderal species in the Rubus stand. Disc and rotary ploughing had opposite effects on ruderal species, whereas disc ploughing
Table III. Variation in the species composition explained by explanatory variables (according to the Canonical Correspondence Analysis) and level of significance (Monte Carlo test).

\begin{tabular}{lcc}
\hline Explanatory variable & $\begin{array}{c}\text { Variance explained } \\
\text { by single variable }\end{array}$ & $P$-level \\
\hline Glyphosate & 0.21 & 0.002 \\
Soil compaction & 0.14 & 0.002 \\
Rotary plough & 0.11 & 0.002 \\
Clearing saw & 0.07 & 0.002 \\
Roller & 0.11 & 0.002 \\
Soil moisture & 0.04 & 0.010 \\
Disc plough & 0.07 & 0.020 \\
Asulam & 0.04 & 0.024 \\
Harrow & 0.04 & 0.684 \\
Brush cutter & 0.04 & 0.714 \\
\hline
\end{tabular}

favoured stress-tolerant species in the Pteridium stand. These two tillage techniques also had various effects on species richness and diversity depending on the original vegetation type, although the overall trend is an increase in the number of species and diversity. The use of glyphosate against Rubus fruticosus showed a positive influence on species richness and diversity, while the use of asulam against Pteridium aquilinum had a negative effect on species richness and diversity. 
Table IV. Species which were significantly influenced by vegetation and soil treatments, according to the Indicator Species Analysis with a Monte Carlo test of significance (1000 permutations). The table shows the indicator value of each species (\% of perfect indication, based on combining the values for relative abundance and relative frequency). Negative values indicate those species that were negatively influenced (limited) by the treatments. In all other cases, the species were positively influenced (promoted) by the treatments.

\begin{tabular}{|c|c|c|c|c|c|c|c|c|}
\hline $\begin{array}{|ll|}\text { Pteridium } & \text { No veg. } \\
\text { Holcus } & \text { Rubus }\end{array}$ & $\begin{array}{l}\text { Brush } \\
\text { cutter }\end{array}$ & $\begin{array}{c}\text { Clearing } \\
\text { saw }\end{array}$ & Harrow & Disc plough & $\begin{array}{l}\text { Rotary } \\
\text { plough }\end{array}$ & Roller & Asulam & Glyphosate \\
\hline Carex remota & $\left|\begin{array}{ll}52 * & \\
& 59 *\end{array}\right|$ & $\begin{array}{lll}59 * * & \\
& 45 *\end{array}$ & & $54^{*}$ & & & & $51 * * *$ \\
\hline \begin{tabular}{|l|} 
Dryopteris \\
dilatata \\
\end{tabular} & & $29 *$ & & & & $42 *$ & & \\
\hline \begin{tabular}{|l|} 
Epilobium \\
angustifolium
\end{tabular} & & & & & $\begin{array}{l}8^{*} \\
15^{*} \\
\end{array}$ & & & \\
\hline Holcus mollis & & & & $11^{*}$ & & & & \\
\hline $\begin{array}{l}\text { Hypericum } \\
\text { pulchrum }\end{array}$ & & & & $20 *$ & $27 * *$ & $27^{*}$ & & \\
\hline \begin{tabular}{|l|} 
Impatiens \\
parviflora
\end{tabular} & & & & $41 * * *$ & & & & $46 * * *$ \\
\hline Juncus effusus & $\begin{array}{|ll|}50 * * & \\
& 54 * \\
\end{array}$ & $55^{* * * *}$ & & $\begin{array}{l}38 * \\
11 *\end{array}$ & $53 * * *$ & & $-47 * *$ & $41 *$ \\
\hline $\begin{array}{l}\text { Lamium } \\
\text { galeobdolon }\end{array}$ & & & & $34 * *$ & $33 * *$ & & & \\
\hline Oxalis acetosella & $50 *$ & & & & $\begin{aligned} & 67 * * * \\
& 41 * * \\
&\end{aligned}$ & $54^{*} 52^{* * *}$ & & $42 * *$ \\
\hline \begin{tabular}{|l} 
Pteridium \\
aquilinum
\end{tabular} & & & & & $60 * *$ & & $-63 * *$ & \\
\hline Rubus fruticosus & $58^{* * *}$ & & $58 * *$ & $63 * * * 34 *$ & $37 * *$ & $37 *$ & & $-60 * *$ \\
\hline Rubus idaeus & & & & & $20^{*}$ & $13 *$ & & \\
\hline Stachys sylvatica & & & & $37 * *$ & $36 * *$ & & & \\
\hline Urtica dioica & & & & & $16^{*}$ & & & $20 * *$ \\
\hline Veronica montana & & $18^{*}$ & & & & & & \\
\hline
\end{tabular}

$* P<0.05 ; * * P<0.01 ; * * * P<0.001$.

\section{DISCUSSION}

Of the 29 species recorded, 15 showed a significant recovery after soil treatment (combined or not with vegetation treatment) in the studied forest area. Of course, results are strongly dependent on the composition of the seed bank and the vegetation type. For instance, as Carex remota, Dryopteris dilatata and Rubus fruticosus are very abundant in the seed bank of our study area [22], it is not surprising that they were among the most frequent species found after treatment implementation.
Interestingly, different cutting treatments (brush cutter vs. clearing saw) or tillage treatments (disc vs. rotary plough) did not have the same influence on plant establishment. In an experiment on a brown forest soil in Hungary, Farkas [16] also found various effects of soil treatments on plant composition, and he could rank the tillage systems as follows on the basis of decreasing weed cover: direct drilling $>$ field cultivator $>$ ploughing $>$ loosening + disking. In our experiment, species that are undesirable in a forest ecosystem, such as competitors and ruderals, were promoted in only one stand by rotary ploughing, while they were limited by disc ploughing in two 
Table V. Influence of different vegetation and soil treatments on soil parameters and vegetation characteristics. C-strategists: competitors; Sstrategists: stress-tolerators; R-strategists: ruderals; F-index: soil moisture index; L-index: light index; N-index: soil nutrient index; R-index: soil reaction index. Figures shown are mean values. Probability levels according to Mann-Whitney $U$-tests.

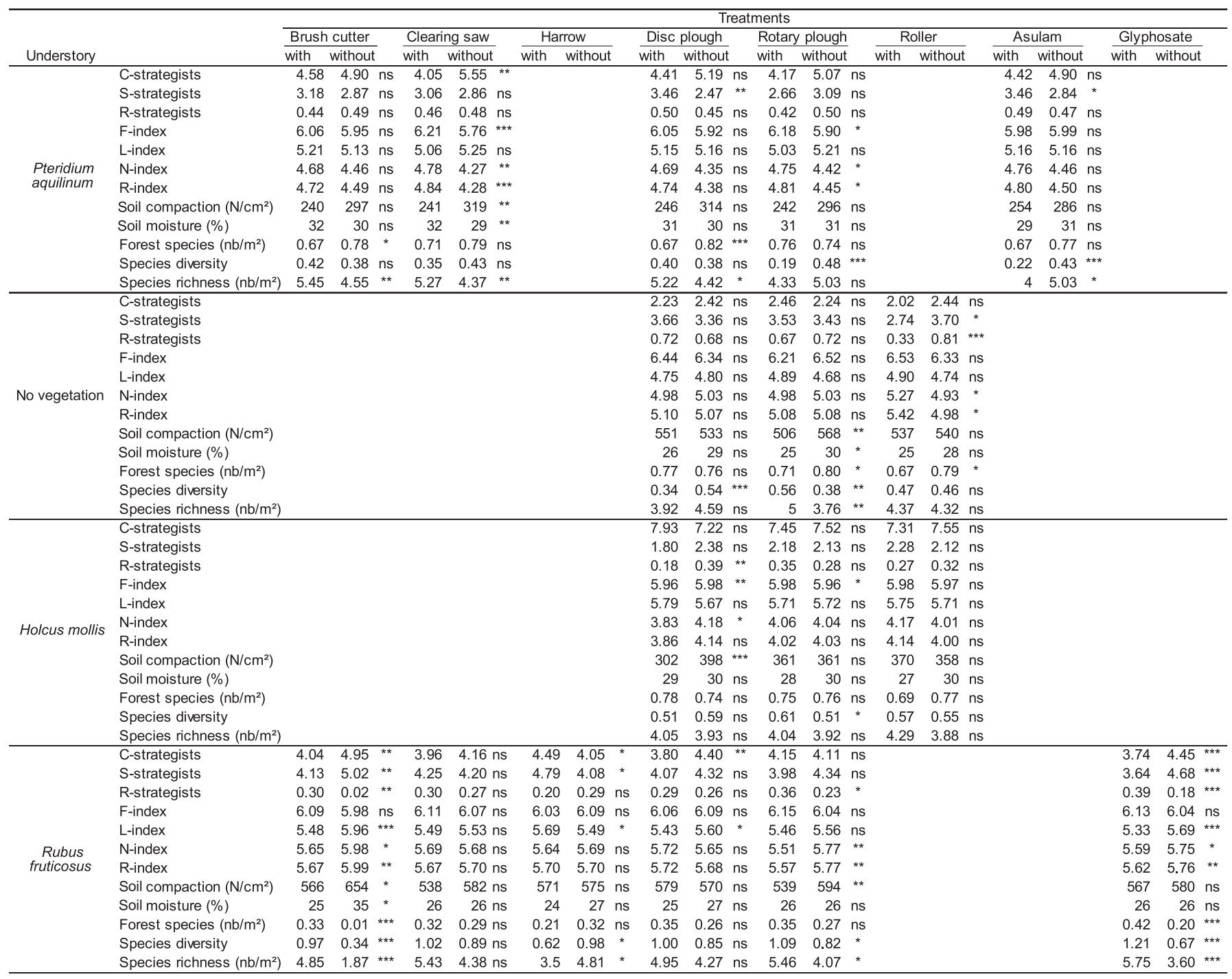

$* P<0.05 ; * * P<0.01 ; * * * P<0.001$. ns: not significant.

of the four investigated stands. Forest species were not particularly promoted by both ploughing techniques. This study allowed us to acquire more specific information on the potentiality of soil loosening as a technique to restore valuable understory species in degraded forest ecosystems. By valuable understory, we mean a herb layer where the diversity of forest dwellers is maximised while competitive, ruderal or nitrophilous species remain at a low level. As these patterns were never clear-cut, we cannot say that soil tillage makes possible the restoration of a typical forest understory in degraded forest ecosystems. It is commonly argued that shadetolerant understory herbs do not appear very much in forest seed banks [50], and that these species rely on clonal growth to expand under the canopy [27]. This could partly explain our results, together with the dominance for several years of one understory species, which is not favourable for the development of a diversified seed bank. We have seen however that disc plough, and particularly rotary plough, had a positive effect on the global species richness and diversity. It means that soil loosening, even without vegetation treatment, is able to diversify the understory of forest ecosystems.

Treatment effects on soil structure and/or moisture status can be considered as causing the observed growth response. Indeed, results of this study showed that similar vegetation or soil treatments differently influenced soil properties such as compaction and moisture. We found for example that disc plough induced in some cases a reduction in soil compaction and in other cases has no significant effect on it. When it 
happened, the decrease in soil compaction was stronger after disc ploughing than after rotary ploughing. Most of the studies published up to now deal with the comparison between conventional tillage and no-tillage. Licht and Al-Kaisi [45] observed that penetration resistance under no-tillage was generally greater than that of chisel plough, especially in the top $20 \mathrm{~cm}$ soil depth. Nevertheless, their results show a high variability in penetration resistance among different tillage systems, which is in accordance with our results.

The fact that distinct tillage methods do show various effects on soil structure could be due to their different action on soil porosity $[1,3,38]$. One could therefore assume that the proportion of cryptopores, micropores and macropores is not the same after disc vs. rotary ploughing. In fact these types of tilling are quite different: rotary ploughing is a cultivation that mixes the soil over the whole surface, while disk plough is really ploughing the soil, i.e. a tillage operation in which the soil is turned over. Hence, the rearrangement of the soil components is different (mix of soil aggregates, organic material, etc.) and consequently the pore size distribution.

The shape of soil aggregates produced by tillage is also important for predicting the density of seed beds. Smooth aggregates pack more easily than irregular ones of the same size [51]. Soil smoothness or roughness is therefore another possible explanation for the different effects observed between disc and rotary plough. Infiltration, evaporation and runoff retardation are closely associated with random roughness, the latter being higher in tilled plots than in control plots [29].

A higher amount of very coarse (water conductivity) pores in non-tilled soils as compared to mechanically tilled soils has been reported [3]. One may therefore state that the soils also become more water permeable after treatment [38]. In our study, conflicting results were found between measured soil moisture and calculated moisture index. As soil moisture is highly variable and depends on meteorological circumstances, we believe that calculated moisture indices represent a more confident picture as they integrate moisture status throughout several years, while our measurements were taken at one moment. Considering this, we found that both disc and rotary ploughing decreased calculated soil moisture. This is likely due to the fact that tilling the soils enhanced infiltration rates as found by Geissen et al. [20] and Guzha [29]. Field experiments under Nordic conditions have shown that on clay and silty clay soils, the soil water content was higher after shallow tillage $(6 \mathrm{~cm})$ than after conventional tillage $(25 \mathrm{~cm})$ [2]. Similarly, the study of Azooz et al. [3], conducted on a silt loam and on a sandy loam, showed that both soils retained more water under no-tillage than under conventional tillage.

Both disc and rotary ploughing have been found to induce a nitrogen-depleting effect in the tilled soils. This is consistent with existing knowledge. Nitrate leaching and loss of organic carbon after tillage are often very strong in the initial phase, i.e. in the first year following the treatment [20]. The organic $\mathrm{C}$ and total $\mathrm{N}$ supply can decrease because of plant uptake, leaching processes or gaseous escape [6]. In our experiment, nitrate leaching was not measured but inferred via Ellenberg's indices. This means that even if the process takes place very quickly after tillage, its effects on the vegetation are lasting. Remarkably, soil tillage effects were also still detectable four years after the implementation of the treatments, although one could expect to find the opposite pattern, like Guzha [29] for instance, found that with cumulative rainfall, random roughness deteriorated drastically, and at the end of the season the values were almost the same for all tillage methods. This could mean that both disc and rotary ploughing are producing stable aggregates. Indeed, stable aggregates are required to prevent puddling and poor physical conditions from reappearing shortly after tillage [10].

Contrary to previous works, this study has shown that tillage may have a lasting effect on soil physical properties and vegetation characteristics. Furthermore, different tillage methods do not have the same effect on soil physical properties and on plant establishment. However, different points should be kept in mind: (1) these techniques were implemented in combination with mechanical or chemical control of the initial competitive understory vegetation, which definitely improved the results of the experiment; (2) results are highly dependent on the initial vegetation type and on soil seed bank composition. We therefore encourage additional experiments in different stand and soil types in order to establish the generality of these particular findings.

Acknowledgements: This study was made possible thanks to the experimental plots that have been put in place in the framework of the project "Natural Regeneration of Beech in the Sonian Forest", financed through the King Baudouin Foundation by the special fund of the "Generale maatschappij van België", group Suez. Some analyses synthesized in this paper were performed with financial support provided by the Brussels Institute for Environmental Management (IBGE-BIM). We thank Fabienne Van Rossum for her advice in statistical data processing.

\section{REFERENCES}

[1] Arshad M.A., Franzluebbers A.J., Azooz R.H., Components of surface soil structure under conventional and no-tillage in northwestern Canada, Soil Till. Res. 53 (1999) 41-47.

[2] Aura E., Effects of shallow tillage on physical properties of clay soil and growth of spring cereals in dry and moist summers in southern Finland, Soil Till. Res. 50 (1999) 169-176.

[3] Azooz R.H., Arshad M.A., Franzluebbers A.J., Pore size distribution and hydraulic conductivity affected by tillage in northwestern Canada, Soil Sci. Soc. Am. J. 60 (1996) 1197-1201.

[4] Azooz R.H., Lowery B., Daniel T.C., Arshad M.A., Impact of tillage and residue management on soil heat flux, Agric. For. Meteorol. 84 (1997) 207-222.

[5] Balbuena R., Mac Donagh P., Marquina J., Jorajuria D., Terminiello A., Claverie J., Wheel traffic influence on poplar regeneration and grass yield, Biosyst. Eng. 81 (2002) 379-384.

[6] Ballard T.M., Impacts of forest management on northern forest soils, For. Ecol. Manage. 133 (2000) 37-42.

[7] Bayhan Y., Kayisoglu B., Gonulol E., Effect of soil compaction on sunflower growth, Soil Till. Res. 68 (2002) 31-38.

[8] Birkas M., Gyuricza C., Gecse M., Percze A., Effect of repeated shallow disk tillage on some crop production factors on brown forest soil, Novenytermeles 48 (1999) 387-402.

[9] Buckley D.S., Crow T.R., Nauertz E.A., Schulz K.E., Influence of skid trails and haul roads on understory plant richness and composition in management forest landscapes in Upper Michigan, USA, For. Ecol. Manage. 175 (2003) 509-520. 
[10] Bulmer C., Reclamation of forest soils with excavator tillage and organic amendments, For. Ecol. Manage. 133 (2000) 157-163.

[11] Da Silva A.P., Kay B.D., Perfect E., Management versus inherent soil properties effects on bulk density and relative compaction, Soil Till. Res. 44 (1997) 81-93.

[12] Dagnelie P., Palm R., Rondeux J., Thill A., Tables de cubage des arbres et des peuplements forestiers, Presses Agronomiques de Gembloux, Gembloux, 1999.

[13] De Vos B., Bodemcompactie en de invloed op de natuurlijke verjonging van beuk in het Zoniënwoud, Report IBW.bb R 2005.004, Instituut voor Bosbouw en Wildbeheer, Geraardsbergen, 2005.

[14] Dufrêne M., Legendre P., Species assemblages and indicator species: the need for a flexible asymmetrical approach, Ecol. Monogr. 67 (1997) 345-366.

[15] Ellenberg H., Weber H.E., Düll R., Wirth V., Werner W., Paulissen D., Zeigerwerte von Pflanzen in Mitteleuropa, Scr. Geobot. 18 (1991) 1-248.

[16] Farkas A., Evaluation of tilling systems from the point of view of weed control on brown forest soil in Godollo, Novenytermeles 51 (2002) 513-528

[17] Froehlich H.A., Soil damage, tree growth, and mechanization of forest operations, in: Seminar on the impact of mechanization of forest operations on the soil, Louvain-La-Neuve, Belgium, 1989, pp. 76-86.

[18] Froehlich H.A., Miles D.W.R., Robbins R.W., Soil bulk density recovery on compacted skid trails in Central Idaho, Soil Sci. Soc. Am. J. 49 (1985) 1015-1017.

[19] Gecse M., Galovics A., Effect of traditional and reduced tillage on the soil status, Novenytermeles 50 (2001) 237-247.

[20] Geissen V., Kim R.-Y., Schöning A., Schütte S., Brümmer G.W., Effects of strip wise tillage in combination with liming on chemical and physical properties of acidic spruce forest soils after clear cutting, For. Ecol. Manage. 180 (2003) 75-83.

[21] Godefroid S., Koedam N., Interspecific variation in soil compaction sensitivity among forest floor species, Biol. Conserv. 119 (2004) 207-217.

[22] Godefroid S., Phartyal S., Koedam N., Depth distribution and composition of seed-banks under different tree layers in a managed temperate forest ecosystem, Acta Oecol. 29 (2006) 283-292.

[23] Godefroid S., Rucquoij S., Koedam N., Spatial variability of summer microclimates and vegetation response along transects within clearcuts in a beech forest, Plant Ecol. 185 (2007) 107-121.

[24] Gomez A., Powers R.F., Singer M.J., Horwath W.R., Soil compaction effects on growth of young ponderosa pine following litter removal in California's Sierra Nevada, Soil Sci. Soc. Am. J. 66 (2002) 1334-1343.

[25] Grigal D.F., Effects of extensive forest management on soil productivity, For. Ecol. Manage. 138 (2000) 167-185.

[26] Grime J.P., Hodgson J.G., Hunt R., Comparative plant ecology. A functional approach to common British species, Unwin-Hyman, London, 1988.

[27] Grime J.P., Plant strategies, vegetation processes, and ecosystem properties, John Wiley \& Sons, Chichester, 2001.

[28] Grzesiak S., Grzesiak M.T., Felek W., Hura T., Stabryla J., The impact of different soil moisture and soil compaction on the growth of triticale root system, Acta Physiol. Plant. 24 (2002) 331-342.

[29] Guzha A.C., Effects of tillage on soil microrelief, surface depression storage and soil water storage, Soil Till. Res. 76 (2004) 105-114.

[30] Herbauts J., El Bayad J., Gruber W., Influence of logging traffic on the hydromorphic degradation of acid forest soils developed on loessic loam in middle Belgium, For. Ecol. Manage. 87 (1996) 193-207.
[31] Herbauts J., El Bayad J., Gruber W., The impact of mechanized forestry techniques on the physical deterioration of soils - The case of acid, silty soils in the Soignes Forest (Belgium), Rev. For. Fr. 2 (1998) 124-137 (in French).

[32] Hildebrand E.E., The influence of soil compaction on soil functions in forest sites, in: Seminar on the impact of mechanization of forest operations on the soil, Louvain-La-Neuve, Belgium, 1989, pp. 149-164.

[33] Hill M.O., Mountford J.O., Roy D.B., Bunce R.G.H., Ellenberg's indicator values for British plants, Institute of Terrestrial Ecology, Huntingdon, 1999.

[34] Hill M.O., Roy D.B., Thompson K., Hemeroby, urbanity and ruderality: bioindicators of disturbance and human impact, J. Appl. Ecol. 39 (2002) 708-720.

[35] Hillel D., Environmental soil physics, Academic Press, San Diego, 1998.

[36] Holshouser D.L., Soybean production guide, Tidewater Agricultural Research and Extension Center, Information Series No. 408, 2001.

[37] Jansson K.J., Wasterlund I., Effect of traffic by lightweight forest machinery on the growth of young Picea abies trees, Scand. J. For. Res. 14 (1999) 581-588.

[38] Józefaciuk G., Muranyi A., Szatanik-Kloc A., Farkas C., Gyuricza C., Changes of surface, fine pore and variable charge properties of a brown forest soil under various tillage practices, Soil Till. Res. 59 (2001) 127-135.

[39] Kaspar T.C., Erbach D.C., Cruse R.M., Corn response to seed-row residue removal, Soil Sci. Soc. Am. J. 54 (1990) 1112-1117.

[40] Khan A.R., Influence of tillage on soil aeration, J. Agron. Crop. Sci. 177 (1996) 253-259.

[41] Kozlowski T.T., Soil compaction and growth of woody plants, Scand. J. For. Res. 14 (1999) 596-619.

[42] Lambinon J., De Langhe J.E., Delvosalle L., Duvigneaud J., Flora van België, het Groothertogdom Luxemburg, Noord-Frankrijk en de aangrenzende gebieden, Nationale Plantentuin van België, Meise, 1998.

[43] Langmaack M., Schrader S., Rapp-Bernhardt U., Kotzke K., Soil structure rehabilitation of arable soil degraded by compaction, Geoderma 105 (2002) 141-152.

[44] Larney F.J., Bullock M.S., Influence of soil wetness at time of tillage implement on soil properties affecting wind erosion, Soil Till. Res. 29 (1994) 83-95.

[45] Licht M.A., Al-Kaisi M., Strip tillage effect on seedbed soil temperature and other soil physical properties, Soil Till. Res. 80 (2005) 233-249.

[46] Lieth H., Berlekamp J., Fuest S., Riediger S., Climate Diagram World Atlas, CD-Series, Climate and Biosphere, Backuys Publishers, Leiden, 1999.

[47] Louis A., Carte des sols de la Belgique. Texte explicatif de la planchette d'Uccle 102W, IRSIA, Brussels, 1959.

[48] McCune B., Mefford M.J., PC-ORD. Multivariate analysis of ecological data. Version 3.0, MjM Software Design, Gleneden Beach, Oregon, 1997.

[49] Nevens F., Reheul D., The application of vegetable, fruit and garden waste (VFG) compost in addition to cattle slurry in a silage maize monoculture: nitrogen availability and use, Eur. J. Agron. 19 (2003) 189-203.

[50] Olano J.M., Caballero I., Laskurain N.A., Loidi J., Escudero A., Seed bank spatial pattern in a temperate secondary forest, J. Veg. Sci. 13 (2002) 775-784

[51] Perfect E., Kay B.D., Applications of fractals in soil and tillage research: a review, Soil Till. Res. 36 (1995) 1-20. 
[52] Rab M.A., Recovery of soil physical properties from compaction and soil profile disturbance caused by logging of native forest in Victorian Central Highlands, Australie, For. Ecol. Manage. 191 (2004) 329-340.

[53] Rosolem C.A., Foloni J.S.S., Tiritan C.S., Root growth and nutrient accumulation in cover crops as affected by soil compaction, Soil Till. Res. 65 (2002) 109-115.

[54] Seixas F., McDonald T., Soil compaction effects of forwarding and its relationship with 6- and 8-wheel drive machines, For. Prod. J. 47 (1997) 46-52.

[55] Small C.J., McCarthy B.C., Effects of simulated post-harvest light availability and soil compaction on deciduous forest herbs, Can. J. For. Res. 32 (2002) 1753-1762.

[56] Soane B.D., Ball B.C., Review of management and conduct of longterm tillage studies with special reference to a 25 -yr experiment on barley in Scotland, Soil Till. Res. 45 (1998) 17-37.

[57] Startsev A.D., McNabb D.H., Effects of skidding on forest soil infiltration in west-central Alberta, Can. J. Soil Sci. 80 (2000) 617-624.

[58] Statsoft Inc., STATISTICA (data analysis software system), version 6, Statsoft Inc., Tulsa, 2001.

[59] Stieperaere H., Fransen K., Standaardlijst van de Belgische vaatplanten, met aanduiding van hun zeldzaamheid en sociooecologische groep, Dumortiera 22 (1982) 1-41.
[60] Taboada M.A., Micucci F.G., Cosentino D.J., Lavado R.S., Comparison of compaction induced by conventional and zero tillage in two soils of the Rolling Pampa of Argentina, Soil Till. Res. 49 (1998) 57-63.

[61] Ter Braak C.J.F., Gremmen N.J.M., Ecological amplitudes of plant species and the internal consistency of Ellenberg's indicator values for moisture, Vegetatio 69 (1987) 79-87.

[62] Ter Braak C.J.F., Šmilauer P., CANOCO reference manual and CanoDraw for Windows. User's guide: software for Canonical Ordination, version 4.5, Microcomputer power, Ithaca, NY, 2002.

[63] Vanwijnsberghe S., Management plan proposal for the Sonian Forest. Part Brussels Capital, Brussels Institute for Environmental Management, Forest Department, Brussels, 2002 (in French and Dutch).

[64] Westhoff V., Van der Maarel E., The Braun-Blanquet approach, in: Whittaker R.H. (Ed.), Handbook of vegetation science. Part V: Ordination and classification of vegetation, Dr. W. Junk B.V. Publishers, The Hague, 1973, pp. 619-726

[65] Williamson J.R., Neilsen W.A., The influence of forest site on rate and extent of soil compaction and profile disturbance of skid trails during ground-based harvesting, Can. J. For. Res. 30 (2000) 1196-1205.

[66] Zoebeck T.M., Onstad C.A., Tillage and rainfall effects on random roughness: a review, Soil Till. Res. 9 (1987) 1-31. 